Buana Sains Vol 20 No 1: 7 - 19, 2020

\title{
ANALISA SENYAWA BIOAKTIF ANTIOKSIDAN DAN ZAT GIZI TERHADAP BUAH TERUNG POKAK (Solanum torvum) SEBAGAI BAHAN PANGAN FUNGSIONAL
}

\author{
Nunuk Helilusiatiningsih dan Edy Soenyoto \\ Jurusan Agroteknologi, Fakultas Pertanian Universitas Islam Kadiri, Indonesia
}

\begin{abstract}
Solanum torvum has potential as a functional food ingredient because it contains bioactive antioxidant compounds which are quite high and are proven as herbal medicines in China and are a popular food in Florida, Alabama, West India, Malaysia, Thailand, Mexico, Central America, South America, Brazil. The study aims to analyze the components of bioactive antioxidant compounds and nutrients in qualitative and quantitative methods and functional groups in fresh Solanum torvum. The research method used phytochemical screening, quantitative tests, chemical identification with LCMS, FTIR, AAS. The results of phytochemical screening studies, the Solanum torvum contains few alkaloids, while it contains a great number of saponins, steroids, glycosides. The quantitative test showed that the fruit contains $36.31 \mathrm{mg} / \mathrm{g}$ phenol, 0.62 $\mathrm{mg} / \mathrm{g}$ tannin content, $2.76 \mathrm{mg} / \mathrm{g}$ flavonoid content and antioxidant activity (\% DPPH inhibition) of $84.55 \%, 82.77 \%$ water content, $1.63 \%$ ash content, $2.73 \%$ fat content, 9.78\% protein, $3.69 \%$ carbohydrates, $3.77 \%$ vitamin C, $0.97 \%$ phosphorus, $0.13 \%$ potassium, Ca $36.64 \mathrm{ppm}, \mathrm{Mg} 79.1 \mathrm{ppm}, \mathrm{Fe} 2.34 \mathrm{ppm}$. Chemical tests with LCMS contain 13 types of components namely (1) chlorogenic acid, (2) 4-O-caffeoylquinic, (3) 3-O-caffeoylquinic, (4) 4-O-caffeoylquinic, (5) 3-O-feruloylquinic acid, (6) 5-Oferuloylquinic acid, (7) 3-O-dicaffeoylquinic acid, (8) 4-O-dicaffeoylquinic acid, (9) 3-5O-dicaffeoylquinic acid, (10) 3-O -feruloylquinic acid, (11) 5-O-feruloquinic acid, (12) putative dicaffeoylquiniacid, (13) putativedicaffeoylquinic acid. The functional groups of Solanum torvum have seven types namely phenol $(\mathrm{OH})$, Alkane $(\mathrm{C}-\mathrm{H})$, Alkene $(\mathrm{C}=\mathrm{C})$, aromatic ring, Nitro (NO2), Amine and Amide (C-N), Alcohol (C-O). Thus, fresh Solanum torvum contains potential antioxidant compounds and nutrients that function for health and functional food.
\end{abstract}

Keywords: Antioxidants; herbal; functional food; nutrient substances; Solanum torvum.

\section{Pendahuluan}

Tanaman terung pokak (Solanum torvum) tumbuh subur di wilayah Indonesia sebagai tanaman liar dan masih terbatas budidayanya. Potensi buah terung pokak sebagai obat herbal di luar negeri cukup banyak yang melaporkan sedangkan di Indonesia terbatas penggunaanya. Menurut Jaiswal (2018), terung pokak (Solanum torvum) mengandung glikosida steroid, saponin, flavonoid, kelompok vitamin $\mathrm{B}$, vitamin C, garam besi, alkaloid steroid sebagai antioksidan, kardiovaskuler, dan imunodulator. Hal ini didukung pendapat Mohan et al. (2010), bahwa buah Solanum torvum mengandung flavonoid, alkaloid, 
N Helilusiatiningsih dan E. Soenyoto / Buana Sains Vol 20 No 1 : 7-19

tanin, saponin, berfungsi sebagai antioksidan. Adanya senyawa metil kafeat pada buah terung pokak (Solanum torvum) berfungsi sebagai anti kanker (Balachandran, 2015).

Permasalahan terung pokak di Indonesia masih terbatas penggunaanya sebagai bahan pangan karena belum banyak dibudidayakan dan digunakan sebagai makanan kuliner atau belum banyak dijual dipasar serta swalayan. Di luar negeri terung pokak terkenal dengan nama turky berry, dikonsumsi dalam bentuk segar dan olahan penduduk Florida, Alabama, India Barat, Malaysia, Thailand, Mexiko, Amerika Tengah, Amerika Selatan, Brasil. Konsumsi turkey berry segar dijual di super market dan bentuk olahan contohnya jus, sup, pladuk phat phet, thai chili pastes, lao cusisine dan sold at morning (Langeland and cherry, 2008). Terung pokak (Solanum torvum) di Indonesia dikonsumsi bentuk olahan seperti campuran nasi goreng, tumis, oseng, aneka sambel, sayur sop, botok (Agustina et al., 2017).

Pasca panen terung pokak juga mendorong kerusakan akibat proses respirasi aerobik dan kontaminasi mikroba. Terong pokak menurut Jaiswal (2018), adalah buah buni yang daunnya berbentuk bulat telur, tumbuh berselang seling, panjangnya $10-15 \mathrm{~cm}$, lebar $8-10$ $\mathrm{cm}$. Bijinya pipih warnanya coklat panjangnya 1,5-2 mm. Baunya mirip lada, rasanya pahit dan tajam. Menurut laporan Karmakal et al., (2015), Buah terong pokak yang diekstrak dengan pelarut eter mengandung steroid, saponin, tanin, terpenoid, alkaloid, asam lemak, asam askorbat. Peneliti lain oleh Bernhot (2010), menjelaskan bahwa senyawa bioaktif flavonoid, terpeneoid, alkaloid, saponin dan fenolik memiliki efek farmakologis yang penting bagi kesehatan tubuh. Mahadeva and
Thenmozhi (2012) menyatakan bahwa analisa fitokimia buah Solanum torvum dengan pelarut air dalam 100 gram bahan memiliki kadar Vit. A 6,12 mg, Kadar Vitamin C 130, 8 mg, Kadar Vitamin E $10,77 \mathrm{mg}$, Polifenol $131,3 \mathrm{mg}$, protein 3.54 gr, Karbohidrat 2,204 gram. Potensi terung pokak di Indonesia sangat perlu dilakukan penelitian untuk mendapatkan informasi kandungan senyawa bioaktif antioksidan dan fitokimia yang terdapat di dalam buah segar. Tanaman ini di Indonesia masih tergolong liar belum banyak dibudidayakan dan tersebar di daerah iklim sub tropik sampai tropik.

Tujuan penelitian ini adalah mempelajari kandungan senyawa bioaktif antioksidan dan zat gizi dengan metode kualitatif dan kuantitatif serta gugus fungsionalnya. Departemen Kesehatan dan Kesejahteraan Jepang telah mengelompokkan senyawa didalam makanan fungsional (nutrisi dan nonnutrisi) menjadi 12 komponen, yaitu serat pangan, oligosakarida (prebiotik), gula alkohol, glikosida, protein tertentu,vitamin, kolin, lesitin, bakteri asam laktat (probiotik), asam lemak tak jenuh rantai panjang, mineral, fitokimia, dan antioksidan (Sloan, 2002). Manfaatnya untuk memberi informasi kandungan senyawa kimia yang bermanfaat bagi kesehatan tubuh sebagai bahan pangan fungsional dan bersifat kebaruan.

\section{Metode Penelitian}

Penelitian ini menggunakan Terung pokak sebagai bahan baku utama yang diperoleh dari desa Sumber Manjing Kulon Kabupaten Malang. Selain itu, untuk analisa uji aktifitas antioksidan dilakukan dengan metode DPPH dengan menggunakan 2,2 difenil-1-pikrilhidrazil/ larutan DPPH 0,1 mM, Blanko (kontrol) menggunakan etanol pengganti sampel. Uji fenol menggunakan reagen FC yang 
N Helilusiatiningsih dan E. Soenyoto / Buana Sains Vol 20 No 1 : 7-19

merupakan campurann tungsten dan molibdenum oksida, metal oksida, asam galat, sodium carbonat, akuades, etanol. Uji flavonoid menggunakan alumanium chlorida, Quercetin, akuades, $\mathrm{NaNO}_{2} .5$ $\%, \mathrm{NaOH} 1 \mathrm{M}$. Uji saponin dilakukan dengan menggunakan $\mathrm{HCl}$, metanol, petroleum eter, etil asetat, $\mathrm{n}$ butanol. Sedangkan uji tanin dengan katekin, metanol vanilin $4 \%$, serta $\mathrm{HCl}$. Uji protein dilakukan dengan campuran selen, campuran 2,5gr serbuk $\mathrm{SeO}_{2}, 100 \mathrm{~g}$ $\mathrm{K}_{2} \mathrm{SO}_{4}, 30$ g $\mathrm{CuSO}_{4} 5 \mathrm{H}_{2} \mathrm{O}$, indikator campuran, Larutan bromocresol green $0,1 \%$, larutan merah metal $0,1 \%$ dalam alkohol, larutan asam borat $2 \%, \mathrm{HCl} 0,01$ $\mathrm{N}, \mathrm{NaOH} 30 \%$, air, asam sulfat pekat, alkohol, air, akuades, sampel.

\section{Uji skrening Fitokimia \\ a. Skrining Alkaloid}

Pada Skrining alkaloid dilakukan dengan cara simplisia 0,5 g ditimbang, ditambahkan $1 \mathrm{ml}$ asam klorida $2 \mathrm{~N}$ dan $9 \mathrm{ml}$ air suling. Campuran dipanaskan selama 2 menit, didinginkan dan disaring. Filtrat yang didapatkan untuk analisa alkaloid: menyiapkan 3 tabung reaksi, kemudian dimasukkan $0,5 \mathrm{ml}$ filtrate, setiap tabung reaksi:. ditambahkan 2 tetes pereaksi Mayer dan 2 tetes pereaksi Bouchardat lalu ditambah 2 tetes pereaksi Dragendroff. Alkaloida positif jika terjadi endapan atau kekeruhan.

\section{b. Skrining glikosida}

Skrining glikosida dilakukan dengan cara simplisia $3 \mathrm{~g}$ ditimbang kemudian ditambah $30 \mathrm{ml}$ campuran etanol 95\% dengan air (7:3) dan $10 \mathrm{ml}$ asam klorida 2 N. Campuran direfluks selama 2 jam, didinginkan dan disaring. Diambil $20 \mathrm{ml}$ filtrat ditambahkan $25 \mathrm{ml}$ air suling dan $25 \mathrm{ml}$ timbal (II) asetat $0,4 \mathrm{M}$, dikocok, didiamkan 5 menit lalu disaring. Filtrat disari dengan $20 \mathrm{ml}$ campuran isopropanol dan kloroform (2:3), diulang sebanyak 3 kali. Sari air dikumpulkam dan diuapkan pada temperatur tidak lebih dari $50^{\circ}$ C. Sisanya dilarutkan dalam $2 \mathrm{ml}$ metanol. Larutan sisa digunakan untuk percobaan berikut: $0,1 \mathrm{ml}$ larutan percobaan dimasukkan dalam tabung reaksi dan diuapkan di atas penangas air. Pada sisa ditambahkan $2 \mathrm{ml}$ air dan 5 tetes pereaksi Molish. Kemudian secara perlahan-lahan ditambahkan $2 \mathrm{ml}$ asam sulfat pekat melalui dinding tabung, terbentuknya cincin berwarna ungu pada batas kedua cairan menunjukkan glikosida

\section{c. Skrining saponin}

Pada skrining saponin simplisia ditimbang $0,5 \mathrm{~g}$ dan dimasukkan ke dalam tabung reaksi, kemudian ditambah $10 \mathrm{ml}$ air panas. Campuran dinginkan lalu dikocok selama 10 detik. Apabila terbentuk busa setinggi $1-10 \mathrm{~cm}$ yang stabil sekitar 10 menit dan tidak hilang dengan penambahan 1 tetes asam klorida $2 \mathrm{~N}$ menunjukkan adanyan senyawa saponin

\section{d. Skrining Steroida}

Skrining steroida dilakukan dengan menimbang $1 \mathrm{~g}$ simplisia lalu dimaserasi dengan $20 \mathrm{ml} n$-heksan selama 2 jam, lalu disaring. Filtrat diuapkan dan pada sisanya ditambah pereaksi LiebermannBurchard, adanya warna biru atau biru hijau menunjukkan senyawa steroid, sedangkan warna merah, merah muda atau ungu menunjukkan senyawa triterpenoid.

\section{e. Uji Aktifitas Antioksidan}

Pada uji aktifitas antioksidan dilakukan dengan menyiapkan $2 \mathrm{~mL}$ sampel untuk selanjutnya ditambahkan 2 $\mathrm{mL}$ metanol $95 \%$ dan $2 \mathrm{~mL}$ DPPH dalam metanol 0,2 mM. Campuran larutan di vortex kemudian diinkubasi dalam ruang gelap selama 30 menit. Diukur absorbansinya menggunakan 
N Helilusiatiningsih dan E. Soenyoto / Buana Sains Vol 20 No 1 : 7-19

spektrofotometer panjang gelombang $516 \mathrm{~nm}$. Kontrol (blanko) dibuat sesuai prosedur diatas dengan menggunakan 4 $\mathrm{mL}$ methanol $95 \%$ dan $2 \mathrm{~mL}$ DPPH dalam metanol 0,2 $\mathrm{mM}$

Aktivitas antioksidan dihitung dengan menggunakan rumus:

$$
\begin{aligned}
& \% \text { Aktivitas Antioksidan (Inhibisi) }= \\
& \frac{\text { Absorbansi kontrol -Absorbansi sampel }}{\text { Absrobnsi kontrol }} \times 100 \%
\end{aligned}
$$

\section{f. Uji Fenol}

Uji fenol dengan menggunakan $0,5 \mathrm{~mL}$ sampel diambil lalu dimasukkan kedalam tabung reaksi. Ditambah $0,5 \mathrm{~mL}$ reagen folin ciocalteu dan $2 \mathrm{~mL} \mathrm{Na} \mathrm{CO}_{3}$ $7,5 \%$. Campuran diinkubasi selama 2 menit pada suhu ruang. ditambah $7 \mathrm{~mL}$ aquades ke dalam tabung reaksi, dan divortex. Campuran diinkubasi selama 30 menit pada suhu ruang. Absorbansi larutan diukur pada panjang gelombang $(\Lambda) 765 \mathrm{~nm}$. Menghitung nilai $\mathbf{x}$ dari nilai absorbansi sampel dan persamaan kurva standar. Menghitung kadar ekuivalen asam galat untuk volume total $10 \mathrm{~mL}$ dilakukan dengan cara:

$$
\begin{aligned}
& \mathrm{p}=\mathrm{x} .10 \mathrm{~mL} \\
& \text { kadar fenol (mg GAE /g) basis basah : } \\
& \mathrm{p} / \mathrm{massa} \text { sampel } \\
& \text { kadar fenol (mg GAE /g) Basis Kering : } \\
& \frac{\text { kadar fenol basis basah }}{100 \text { \% }-\% \text { kadar air sampel }} x 100 \%
\end{aligned}
$$

\section{g. Uji Flavonoid}

Uji flavanoid dilakukan dengan menggunakan $1 \mathrm{ml}$ larutan ekstrak sampel ditambah $4 \mathrm{~mL}$ aquades, larutan $\mathrm{NaNO}_{2}$ (1:20) 0,3 ml. Setelah 6 menit, kemudian ditambah larutan $\mathrm{AlCl}_{3}$ (1:10) 0,3 ml. Selanjutnya 6 menit kemudian, ditambahkan larutan $\mathrm{NaOH}(1 \mathrm{~mol} / \mathrm{L}) 2$ $\mathrm{ml}$. Kemudian ditambah aquades hingga volume $10 \mathrm{ml}$. Divortex. Selanjutnya diinkubasi 15 menit pada suhu ruang dalam kondisi gelap. Pada ukuran $2 \mathrm{ml}$ dimasukan kedalam kuvet untuk diukur absorbansi pada panjang gelombang 496 $(\Lambda) \mathrm{nm}$. Menghitung nilai $\mathbf{x}$ dari nilai absorbansi sampel dan persamaan kurva standar. Menghitung kadar ekuivalen quercetin untuk volume total $10 \mathrm{~mL}$ dilakukan dengan cara:

$\mathrm{p}=\mathrm{x} .10 \mathrm{~mL}$

kadar flavonoid basis basah (mg QE /g) :

$\mathrm{p} /$ massa sampel

kadar flavonoid (mg QE /g) Basis Kering : $\frac{\text { kadar flavonoid basis basah }}{100}$ 96-96 kadar air sampel $x 100 \%$

\section{h. Uji Tannin}

Pada uji tannin dilakukan dengan 0,1 $\mathrm{mL}$ sampel ditambah $0,5 \mathrm{ml}$ folin ciocalteu lalu ditambah dengan $\mathrm{Na}_{2} \mathrm{CO}_{3}$ $35 \%$ sebanyak $1 \mathrm{ml}$ lalu diinkubasi 2 menit suhu ruang. Campuran ditambah aquades hingga total volum $10 \mathrm{~mL}$. Kemudian divortex dan didiamkan selama 30 menit. Selanjutnya diukur absorbansinya menggunakan panjang gelombang maksimum $773 \mathrm{~nm}$. Menghitung nilai $\mathbf{x}$ dari nilai absorbansi sampel dan persamaan kurva standar. Menghitung kadar ekuivalen asam tanat untuk volume total $10 \mathrm{~mL}$

$\mathrm{p}=\mathrm{x} .10 \mathrm{~mL}$

kadar tannin (mg TAE /g) basis basah :

$\mathrm{p} /$ massa sampel

kadar tannin $(\mathrm{mg}$ TAE $/ \mathrm{g})=$

$\frac{\text { kadar tanin basis basah }}{100 \% \text { of kadar air sampel }} \times 100 \%$ :

\section{i. Analisa Kadar Air}

Analisa kadar air dilakukan dengan metode Gravimetri dimana sampel 2-3 gram dihancurkan sampai halus. Kemudian suhu oven diatur pada $105^{\circ} \mathrm{C}$. Selanjutnya siapkan cawan/wadah timbang (dengan tutupnya, jika diperlukan) dan keringkan dalam oven selama minimal 1 jam pada suhu $105^{\circ} \mathrm{C}$. 
N Helilusiatiningsih dan E. Soenyoto / Buana Sains Vol 20 No 1 : 7-19

Kemudian dinginkan selama 30 menit dalam desikator. Timbang wadah timbang yang telah didinginkan tersebut . Timbang contoh yang telah berupa serbuk atau bahan yang telah dihaluskan sebanyak 3 gram dalam botol timbang yang telah diketahui beratnya. Kemudian keringkan dalam oven pada suhu $105^{\circ} \mathrm{C}$ selama 3- 5 jam tergantung bahannya. Dinginkan dalam desikator dan ditimbang. Sampel dikeringkan lagi dalam oven selama 1 jam, didinginkan dalam desikator dan ditimbang, perlakuan ini diulangi sampai tercapai berat konstan (selisih penimbangan berturut-turut kurang dari $0.2 \mathrm{mg}$ ). Kadar air dihitung sebagai persentase kehilangan berat sampel setelah pengeringan yaitu:

Kadar air $=\frac{W}{W 1} X 100 \%$

Keterangan :

$\mathrm{W}=$ bobot cuplikan sebelum dikeringkan $(\mathrm{g})$ $\mathrm{W} 1=$ kehilangan bobot setelah dikeringkan, dalam (g)

\section{j. Analisa Kadar Abu}

Analisa kadar abu dilakukan dengan metode Gravimetri dimana timbang dengan seksama $2 \mathrm{~g}-3 \mathrm{~g}$ bobot contoh ke dalam sebuah cawan porselen yang telah diketahui bobotnya, untuk contoh cairan uapkan di atas pemanas air sampai kering;. Arangkan di atas nyala pembakar, lalu abukan dalam tanur listrik pada suhu maksimum $550^{\circ} \mathrm{C}$ sampai pengabuan sempurna (sekali - kali pintu tanur di buka sedikit, agar oksigen bisa masuk). Dinginkan dalam eksikator, lalu timbang sampai bobot tetap.
Kadar air $\frac{W 1-W 2}{W} X 100 \%$

Keterangan :

$\mathrm{W}:=$ adalah bobot contoh sebelum diabukan $(\mathrm{g})$

W1=adalah bobot contoh + cawan sesudah

diabukan (g)

W2=adalah bobot cawan kosong $(\mathrm{g})$

\section{k. Analisa Kadar Protein}

Analisa kadar protein dilakukan denga metode dimana sampel ditimbang 0,51 g, kemudian masukkan ke dalam labu kjeldahl $100 \mathrm{ml}$. Tambahkan $2 \mathrm{~g}$ campuran selen dan $25 \mathrm{ml} \mathrm{H}_{2} \mathrm{SO}_{4}$ pekat. Panaskan di atas pemanas listrik atau api pembakar sampai mendidih dan larutan menjadi jernih kehijau-hijauan (sekitar 2jam). Biarkan dingin, kemudian encerkan dan masukkan ke dalam labu ukur $100 \mathrm{ml}$, tepatkan sampai tanda garis. Pipet 5 larutan dan masukkan ke dalam alat penyuling tambahkan $5 \mathrm{ml} \mathrm{NaOH} 30$ $\%$ dan beberapa tetes indikator PP. Sulingkan selama lebih kurang 10 menit, sebagai penampung gunakan $10 \mathrm{ml}$ larutan asam borat $2 \%$ yang telah dicampur indikator. Bilasi ujung pendingin dengan air suling. Titar dengan larutan HCI $0.01 \mathrm{~N}$.

\section{Analisa Kadar Lemak Kasar}

Analisa lemak kasar dilakukan dengan menimbang sampel 1 gram. Kemudian masukkan kedalam tabung reaksi $10 \mathrm{ml}$. Tambahkan chloroform mendekati skala. Tutup rapat kemudian kocok dan biarkan bermalam. Saring dengan tissue kedalam tabung reaksi. Pipet $5 \mathrm{ml}$ kedalam cawan yang telah diketahui beratnya. Oven pada suhu 100oC selama 8 jam atau dibiarkan bermalam. Masukkan kedalam desikator lebih kurang 30 menit dan ditimbang. 
N Helilusiatiningsih dan E. Soenyoto / Buana Sains Vol 20 No 1 : 7-19

\section{m. Analisa Vitamin C}

Analisa vitamin C dilakukan dengan uji yodium dimana sampel ditimbang 10 dihaluskan dengan blender lalu dimasukkan ke erlenmeyer yang telah dilapisi alumunium foil lalu dishaker selama 30 menit hingga 1 jam. Hasil maserasi dimasukkan ke dalam labu ukur $100 \mathrm{~mL}$ lalu ditambahkan aquades hingga tanda batas. Campuran sampel dan aquades dihomogenkan, lalu disaring dengan menggunakan kertas saring. Filtrat diambil sebanyak $25 \mathrm{~mL}$ dan dimasukkan ke dalam erlenmyer $250 \mathrm{~mL}$. Ditambahkan $1 \mathrm{~mL}$ amilum 1\% ke dalam Erlenmeyer. Filtrat $+1 \mathrm{~mL}$ amilum dititrasi dengan larutan iodium standar 0,01 N sampai terjadi perubahan warna. Kadar vitamin $\mathrm{C}$ dihitung dengan rumus sebagai berikut :

Vitamin C $(\%)=\frac{\text { ml iodium } x 0,01 N x \frac{100}{\operatorname{as}} x 88 x 100}{\text { berat bahang }}$

\section{n. Analisa kimia terung pokak}

Analisa kimia terung pokak dilakukan melalui uji sampel dengan peralatan LCMS/MS, kolom yang digunakan dengan spesifikasi Hypersil Gold (50 mm x 2,1 $\mathrm{mm} \times 1,9 \mu \mathrm{m}$ ). UHPLC merk ACCELLA type 1250 buatan Thermo Scientific yang terdiri dari degasser vakum, pompa quartener, autosampler termostatk dikendalikan personal komputer melalui program $\mathrm{x}$ calibur 2.1. Pelarut $A=0,1 \%$ basam format dalam air dan $\mathrm{B}=$ asam format dalam Acetonitril. Sebuah gradien fase gerak dengan kecepatan $300 \mu \mathrm{l} /$ menit dengan pengaturan sebagai berikut : 0.00.6.00 menit $5 \%$ B, $0.6-3.0$. adalah 2 $\mu \mathrm{L}$ pada suhu $16^{\circ} \mathrm{C}$. Kolom dikontrol pada suhu $30^{\circ} \mathrm{C}$, dan kompartemen autosampler ditetapkan untuk $16^{\circ} \mathrm{C}$. Penggunaan LCMS/MS Triple menit $75 \%$ B, 3.0 - 3,5 menit $75 \% \mathrm{~B}$, 4.0- 5.5 menit 5\%. Volume injeksi pada Lc Q spektrometermassa TSQ Quantum Access Max dari Thermo Finnigan dengan sumber ionisasi ESI (Electrospray Ionization) dikendalikan oleh software TSQ Tune yang dioperasikan dengan mode negatif. Kondisi Ionisasi ESI adalah sebagai berikut: tegangan spray $3.0 \mathrm{kV}$; suhu penguapan $250^{\circ} \mathrm{C}$; suhu kapiler $300^{\circ} \mathrm{C}$; nitrogen sebagai sheath gas pressure 40 psi, dan aux gas presure 10 psi dengan gas argon.

\section{o. Analisa mineral}

Analisa mineral dilakukan dengan metode AAS dimana analisa logam mengikuti Hukum Lambert- Beer yang menjadi dasar dalam analisis kuantitatif secara spektrofotometer serapanatom (SSA) dengan rumus sebagai berikut: I = Io.ea.b.c atau $\mathrm{A}=$ a.b.c $\operatorname{dengan} \mathrm{A}=$ absorbansi tanpa dimensi , $\mathrm{a}=$ koefisien serapan, $\mathrm{L} 2 / \mathrm{M}, \mathrm{b}=$ panjang jejak sinar dalam medium berisi atom penyerap, L, c $=$ konsentrasi, $\mathrm{M} / \mathrm{L} 3$, Io $=$ Intensitas sinar mula- mula, $\mathrm{I}=$ intensitas sinar yang diteruskan.

\section{p. Analisa Gugus Fungsi.}

Analisa gugus fungsi dilakukan dengan metode FTIR dimana Prinsip kerja spektroskopi FTIR merupakan spektoskopi infra merah yang dilengkapi dengan transformasi Fourier untuk deteksi dan analisis spektrumnya Spektrum inframerah tersebut dihasilkan dari pentrasmisian cahaya yang melewati smpel, pengukuran intensitas cahaya dengan detektor dan dibandingkan dengan intensitas tanpa sampel sebagai fungsi panjang gelombang . Spektrum inframerah yang diperoleh kemudian diplot sebagai intensitas fungsi energi, panjang gelombang $(\mu \mathrm{m})$, dan bilangan gelombang $\left(\mathrm{cm}^{-1}\right)(19)$. 
N Helilusiatiningsih dan E. Soenyoto / Buana Sains Vol 20 No 1 : 7-19

\section{Hasil dan Pembahasan}

\section{Hasil}

Hasil analisa skrening fitokimia menunjukkan buah terung pokak segar mengandung senyawa alkaloid sedikit, memilki kadar saponin, steroid dan glikosida banyak seperti pada Tabel 1 .

Analisa kandungan zat gizi pada buah segar seperti pada Tabel 2 menunjukan kadar air 82,16\%, kadar abu 1,63\%, Lemak 2,73\%, Protein 9,78\%, karbohidrat 3,69\%, Vit C 3,77\% dapat dilihat pada Tabel 2.
Analisa senyawa bioaktif dan aktifitas antioksidan buah terung pokak segar dapat dilihat pada Tabel 3. Hasil analisa menunjukkan kandungan fenol $36,31 \mathrm{mg} / \mathrm{g}$, kadar tanin sebesar 0,62 $\mathrm{mg} / \mathrm{g}$, kadar flavonoid $2,76 \mathrm{mg} / \mathrm{g}$ dan aktivitas antioksidan (\% Hambatan DPPH) sebesar $84,55 \%$.

Hasil uji identifikasi komponen kimia buah terung pokak buah metode LCMS dapat dilihat Gambar 1. dan Tabel 4. Komponen senyawa kimia pada buah terung pokak ada 13 jenis senyawa kimia.

Tabel 1. Hasil Pengamatan skrening fitokimia

\begin{tabular}{|l|l|l|l|l|}
\hline \multirow{2}{*}{ Sampel } & \multicolumn{4}{|c|}{ Skrining Fitokimia } \\
\cline { 2 - 5 } & Alkaloid & Saponin & Steroid & Glikosida \\
\hline Buah Segar & + & +++ & +++ & +++ \\
\hline
\end{tabular}

Keterangan :

$+\quad$ : Sedikit

$++\quad$ : Cukup Banyak

+++ : Banyak

++++ : Sangat Banyak

Tabel 2. Hasil Analisa Zat Gizi Buah Terung Pokak Segar

\begin{tabular}{llcclll}
\hline Sampel & \multicolumn{3}{c}{ Ulangan Perlakuan } & Jumlah & Rerata & $\begin{array}{l}\text { Standart } \\
\text { deviasi }\end{array}$ \\
& 1 & 2 & 3 & & & 0,17 \\
\hline Kadar air (\%) & 82,03 & 82,12 & 82,35 & 246,5 & 82,16 & 0,02 \\
KadarAbu (\%) & 1,65 & 1,64 & 1,61 & 4,9 & 1,63 & 0,12 \\
Protein (\%) & 9,70 & 9,92 & 9,72 & 29,34 & 9.78 & 0,02 \\
Lemak (\%) & 2,71 & 2,72 & 2,75 & 8,19 & 2,73 & 0,19 \\
Karbohidrat (\%) & 3,91 & 3,60 & 3,57 & 11,07 & 3,69 & 0,04 \\
Vitamin C (\%) & 3,81 & 3,78 & 3,73 & 11,31 & 3,77 & \\
\hline
\end{tabular}

Tabel 3 Kandungan Senyawa Bioaktif Buah Terung Pokak Segar

\begin{tabular}{|c|c|c|c|c|c|}
\hline \multirow{2}{*}{ Senyawa Bioaktif } & \multicolumn{3}{|c|}{ Ulangan } & \multirow{2}{*}{$\begin{array}{l}\text { Total } \\
\text { Ulangan }\end{array}$} & \multirow{2}{*}{ Rerata } \\
\hline & $\mathrm{I}$ & II & III & & \\
\hline Fenol (mg GAE/g) & 38.75 & 31.54 & 38.65 & 108.93 & $36.31 \pm 4.13$ \\
\hline Tanin (mg TAE/g) & 0.58 & 0.56 & 0.72 & 1.86 & $0.62 \pm 0.09$ \\
\hline Flavonoid (mg QAE/ g) & 3.05 & 1.93 & 3.30 & 8.28 & $2.76 \pm 0.73$ \\
\hline DPPH (\%INHBISI) & 83.05 & 81.38 & 89.21 & 253.64 & $84.55 \pm 4.12$ \\
\hline
\end{tabular}


N Helilusiatiningsih dan E. Soenyoto / Buana Sains Vol 20 No 1 : 7-19

Tabel 4. Komponen kimia buah terung pokak segar

\begin{tabular}{|c|c|c|c|c|}
\hline No & TR & {$[\mathrm{M}-\mathrm{H}]-(\mathrm{m} / \mathrm{z})$} & $\mathrm{MS}^{2}(\mathrm{~m} / \mathrm{z}$ & Komponen Kimia \\
\hline 1 & 3,72 & 353 & $191 \quad c$ & chlorogenic acid \\
\hline 2 & 4,46 & 353 & 173 & 4-O- caffeoylquinic \\
\hline 3 & 3,90 & 353 & 191 & 3-O- caffeoylquinic \\
\hline 4 & 3,72 & 353 & 193 & 4-O- caffeoylquinic \\
\hline 5 & 5,00 & 367 & 191 & 3-O-feruloylquinic acid \\
\hline 6 & 5,57 & 367 & 193 & 5-O-feruloylquinic acid \\
\hline 7 & 4,97 & 367 & 193 & 3-O-dicaffeoylquinic acid \\
\hline 8 & 7,19 & 352 & 352 & 3,4-O-dicaffeoylquinic acid \\
\hline 9 & 7,04 & 515 & 367 & 3-5-O-dicaffeoylquinic acid \\
\hline 10 & 7,37 & 529 & 367 & 3-O-feruloylquinic acid \\
\hline 11 & 7,52 & 529 & 335 & 5-O-feruloquinic acid \\
\hline 12 & 7,37 & 497 & 335 & putative dicaffeoylquinic acid \\
\hline 13. & 7,69 & 497 & 335 & putative dicaffeoylquinic acid \\
\hline
\end{tabular}

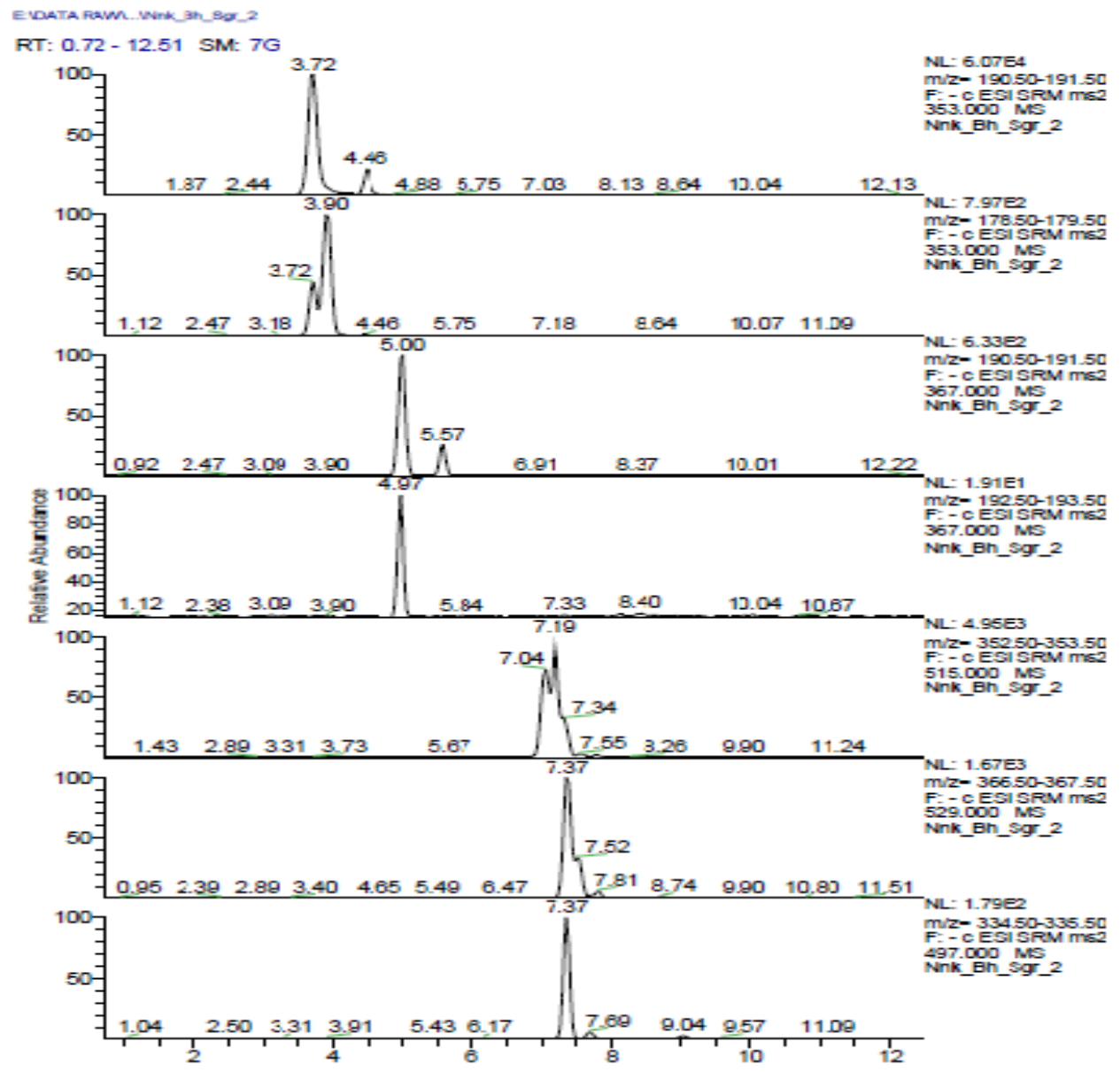

Gambar 1. Spektrum masa dan waktu retensi komponen kimia terung segar dengan menggunakan metode LCMS 
Identifikasi komponen gugus fungsi pada buah terung pokak segar metode FTIR menunjukkan komponen dengan 7 jenis gugus fungsional yaitu fenol $(\mathrm{OH})$, Alkana $(\mathrm{C}-\mathrm{H})$, Alkena $(\mathrm{C}=\mathrm{C})$, Cincin aromatis, Nitro $\left(\mathrm{NO}_{2}\right)$, Amina dan Amida (C-N), Alkohol (C-O) , seperti pada Tabel 5 dan Gambar 2.
Hasil analisa unsur logam pada buah terung pokak segar dengan menggunakan metode AAS menunjukkan kandungan fosfor $0,97 \%$, Kalium 0,13 \%, Kalsium 36,64 ppm, Magnesium 79,1 ppm dan Zat besi sebesar 2,34 ppm seperti pada Tabel 6 .

Tabel 5. Komponen Ikatan, Tipe Senyawa, Frekwensi puncak gelombang

\begin{tabular}{llll}
\hline No & Ikatan & Type Senyawa & Frekwensi $\left(\mathrm{cm}^{-1}\right)$ \\
\hline 1 & O-H & Fenol, alkohol, alkohol ikatan hidrogen & $3200-3600$ \\
2 & C-H & Alkana & $2850-2970$ dan 1340-1470 \\
3 & C=C & Alkena & $1610-1680$ \\
4 & C $=\mathrm{C}$ & Cincin Aromatik & $1500-1600$ \\
5 & $\mathrm{NO}_{2}$ & Nitro & $1500-1570$ dan 1300-1370 \\
6 & $\mathrm{C}-\mathrm{N}$ & Amina dan Amida & $1180-1360$ \\
7 & C-O & Alkohol, Eter, Asam Karboksilat, Ester & $1050-1300$ \\
\hline
\end{tabular}

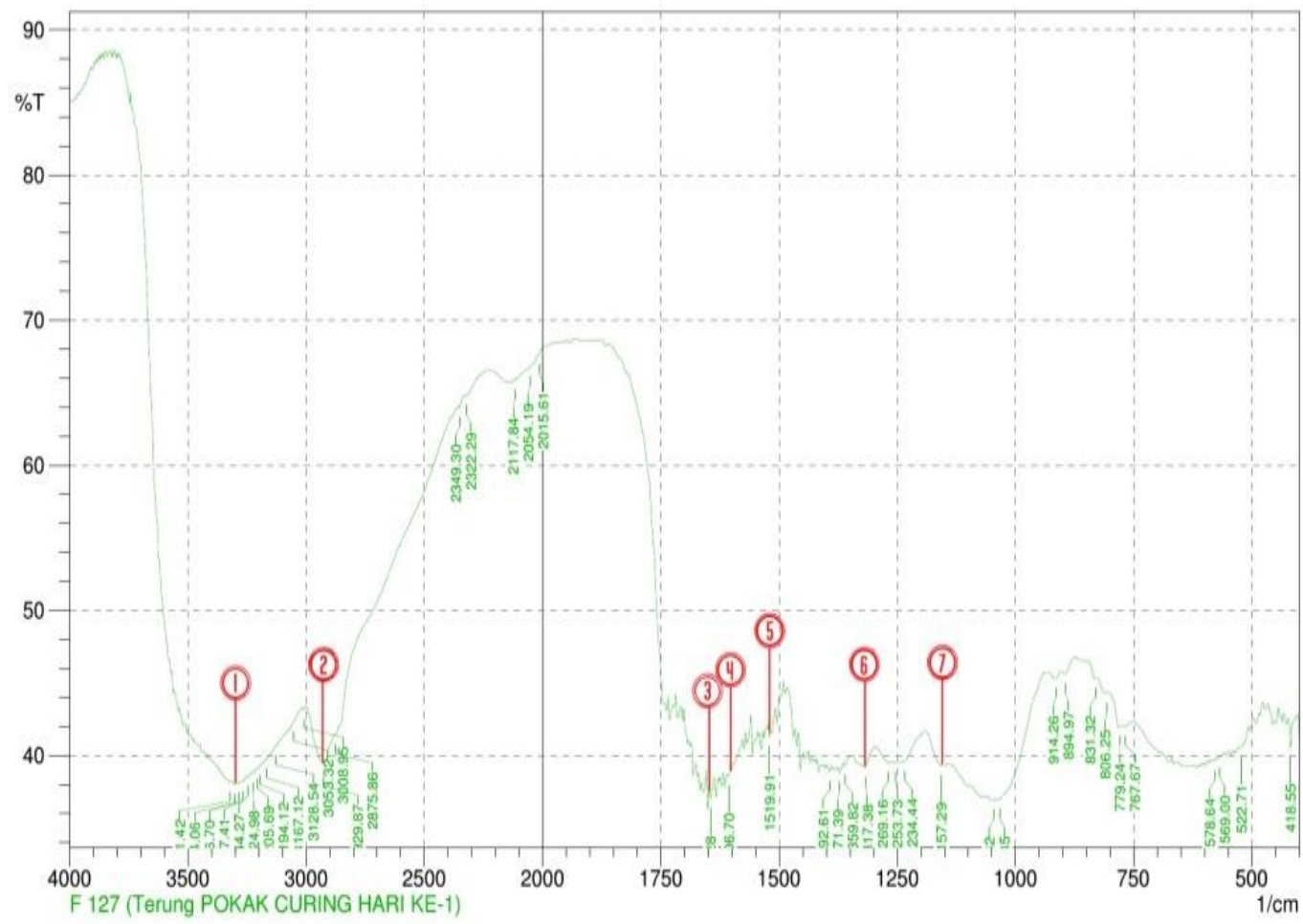

Gambar 2. Hasil analisa Kimia gugus fungsi metode FTIR. 
N Helilusiatiningsih dan E. Soenyoto / Buana Sains Vol 20 No 1 : 7-19

\section{Pembahasan}

Hasil analisa skrening fitokimia buah terung pokak dalam penelitian ini mengandung sedikit alkaloid dan banyak mengandung saponin, steroid dan glikosida. Menurut (Karmakal et al., 2015), buah terong pokak (Solanum torvum) yang diekstrak dengan pelarut eter mengandung steroid, saponin, tanin, terpenoid, alkaloid, asam lemak, asam askorbat. Senyawa bioaktif flavonoid, terpeneoid, alkaloid, saponin dan fenolik memiliki efek farmakologis yang penting bagi kesehatan tubuh (Bernhoft, 2010). Hasil penelitian kandungan gizi buah segar terung pokak pada Tabel 2 menunjukkan kadar air cukup tinggi $82,16 \%$, kadar abu 1,63\%, kadar lemak $2,73 \%$, vitamin C 3,77\% , protein 9,78\% dan karbohidrat sebesar 3,69\%. Menurut Mahadeva dan Thenmozhi (2012) buah Solanum torvum segar mengandung vitamin A 6,12 mg, Vitamin C 130,8 mg, Vitamin E 10,77 mg, Polifenol 151,3 mg, protein 3,54 g, karbohidrat 2,20 $\mathrm{mg}$. Buah terung pokak kering mengandung vitamin A 10,62 mg, vitamin C 100,8 mg, Vitamin E 23,83 mg, polifenol 777,7 mg, protein 3,04 gram, karbohidrat 1,7 gram.

Menurut Andualem and Gessesse (2014), abu merupakan bahan-bahan non organik yang berupa mineral. Kadar mineral yang diperbolehkan dalam produk pangan maksimal 3,5 \% . Analisa kadar abu terung pokak dalam penelitian sebesar 1,63\% jadi masih aman dikonsumsi. Kadar abu terung ungu 0,55\%, kadar abu tomat merah 0,4\%, kadar abu wortel 1,01\%, kadar abu buncis $0,36 \%$, kadar abu tomat hijau $1,61 \%$, kadar abu kacang panjang $0,43 \%$. Kadar abu terung pokak lebih tinggi dibanding terung ungu karena kulit terung pokak lebih tebal dari terung ungu kemungkinan kulit yag tebal banyak mengandung mineral (Rahayu dan Ginanjar, 1997).
Menurut Mahadeva dan Thenmozhi (2012), buah terung pokak (Solanum torvum) segar mengandung protein 3,54 gram dan buah kering memiliki kandungan protein 3,04 gram. Analisa fitokimia buah terung pokak dengan pelarut air dalam 100 gram bahan memiliki kadar Vitamin C sebesar 130, 8 mg. Kandungan karbohidrat buah segar dan kering buah pokak masing-masing 2,20 gram dan 1,7 gram. Menurut Venkatesan and Sujitha (2007) perubahan karbohidrat selama proses pelayuan / penyimpanan suhu kamar disebabkan perlakuan fisik, perombakan secara enzimatis dan proses respirasi oksidatif. Hasil analisa senyawa bioaktif dan aktivitas antioksidan dalam penelitian menunjukkan kandungan fenol 36,31 $\mathrm{mg} / \mathrm{g}$, tanin sebesar $0,62 \mathrm{mg} / \mathrm{g}$, kadar flavonoid 2,76 $\mathrm{mg} / \mathrm{g}$ dan aktivitas antioksidan $(\%$ Hambatan $\mathrm{DPPH})$ sebesar 84,55\%. Kandungan fenol Senyawa antioksidan mempunyai peran sebagai pengganggu proses pembentukan radikal bebas serta dapat mencegah pembentukan hidroperoksida dalam tubuh (Droge, 2002). Hal ini berkaitan dengan keberadaan senyawa antioksidan yang terdapat di dalam buah pokak seperti fenol, tanin, dan flavonoid. Kandungan flavonoid pada terung pokak bertanggung jawab atas aktivitas antioksidan, antihipertensi, proses metabolik dan nephroprotektifnya (Yuan-Lu et al., 2011).

Chah et al., (2000), juga menyebukan bahwa ekstraksi buah pokak dengan pelarut metanol mengandung tanin, alkaloid, saponin, dan steroid. Senyawa Tanin adalah tergolong antioksidan, keberadaan aktioksidan alami dalam tubuh mempunyai peran pengganggu proses pembentukan radikal bebas (Droge, 2002). Golongan flavonoid yang yang memiliki aktivitas 
antioksidan antara lain flavon, flavonol, isoflavon, katetik, flavanon dan khalkon (Sunarmi, 2005).

Keberadaan komponen bioaktif dalam penelitian ini menggunakan metode LCMS (fase diam : Kolom yang digunakan dengan spesifikasi Hypersil Gold $(50 \mathrm{~mm} \times 2.1 \mathrm{~mm} \times 1.9 \mu \mathrm{m})$, fase gerak berupa pelarut $\mathrm{A}=0,1 \%$ asam format dalam Air dan $\mathrm{B}=0,1 \%$ asam formiat dalam Acetonitrile.), GCMS (fase diam : dengan kolom ZB-AAA $(10 \mathrm{~mL} x$ $0,25 \mathrm{mml} . \mathrm{D}$ Phenomenex Inc) dan fase gerak: Gas helium) buah terung pokak segar disajikan pada Gambar 1 dan Tabel 4. Hasil analisa tersebut menunjukkan keberadaan 13 jenis kommponen yaitu (1) chlorogenic acid, (2) 4-O- caffeoylquinic, (3) 3-Ocaffeoylquinic, (4) 4-O-caffeoylquinic, (5) 3-O-feruloylquinic acid, (6) 5-Oferuloylquinic acid, (7) 3-Odicaffeoylquinic acid, (8) 4-Odicaffeoylquinic acid, (9) 3-5-Odicaffeoylquinic acid, (10) 3-Oferuloylquinic acid, (11) 5-O-feruloquinic acid,

dicaffeoylquiniacid,(13)

putativedicaffeoylquinic acid.

Yuan-Lu et al., (2011) menerangkan bahwa buah pokak (Solanum torvum) memiliki zat kimia penyusun seperti neochlorogenin 6-O- $\beta$-D-quinovopyranoside neochlorogenin $6-\mathrm{O}-\beta-\mathrm{D}-$ xylopyranosyl- $(1 \rightarrow 3)-\beta-\mathrm{D}$ -

quinovopyranoside, $6-\mathrm{O}-\alpha-\mathrm{L}-$

rhamnopyranosyl-( $1 \rightarrow 3)$-Dbeta

quinovopyranoside, solagenin $6-\mathrm{O}-\beta-\mathrm{D}-$ quinovopyranoside, solagenin $6-\mathrm{O}-\alpha-\mathrm{L}-$ rhamnopyranosyl $\quad(1 \rightarrow 3)-\beta-\mathrm{D}$ quinovopyranoside, isoquercetin, rutin, kaempferol dan quercetin. Perbedaan komponen kimia pada buah pokak kemungkinan disebabkan menggunakan metode yang berbeda. Hasil identifikasi senyawa biokatif diatas menunjukan bahwa buah segar mengandung banyak senyawa bioaktif antioksidan dan fitokimia. Hal ini didukung pendapat Stevanie et al., (2007), yang menyatakan bahwa buah dari terung pokak diekstrasi dengan etanol mengandung flavonoid, saponin, tanin, alkoloid, steroid, triterpenoid.

Hasil analisa gugus fungsional dengan metode FTIR menunujjukan ada 7 tipe gugus fungsi yaitu fenol $(\mathrm{OH})$, Alkana $(\mathrm{C}-\mathrm{H})$, Alkena $(\mathrm{C}=\mathrm{C})$, Cincin aromatis, Nitro $\left(\mathrm{NO}_{2}\right)$, Amina dan Amida (C-N), Alkohol (C-O) , seperti pada Tabel 5 dan Gambar 2. Hal ini didukung oleh hasil yang didapatkan oleh Wannasirri (2017).

Buah Solanum torvum yang diekstraksi dengan air menghasilkan senyawa fenol, steroid glikosida yang berfungsi sebagai Hiperlipidemia dan hormon sek. Peneliti lain, melaporan bahwa Solanum torvum mengandung flavonoid, alkoloid, tanin, saponin, berfungsi sebagai antioksidan (Mohan et al., 2010). Hasil analisa unsur mineral yang terdapat pada buah terung pokak segar menunjukkan potensi mengandung fosfor, kalium, kalsium, magnesium dan besi seperti pada Tabel 6. Jaiswal (2012), menyatakan bahwa Solanum torvum mengandung glikosida steroid, saponin, flavonoid, kelompok vitamin B, vitamin C, garam besi, alkaloid steroid sebagai antioksidan, kardiovaskuler, serta imunodulator. Buah terung pokak yang diekstrak pelarut eter mengandung steroid, saponin, terpenoid, tanin, alkoloid, besi, asam lemak, asam askorbat (Karmakal et al., 2015).

\section{Kesimpulan}

Hasil analisa senyawa bioaktif antioksidan dan zat gizi pada buah terung pokak segar menunjukkan adanya senyawa alkaloid, saponin, steroid, glikosida, fenol, tanin, flavonoid, asam klorogenik dan derivatnya, kadar air, 
kadar abu, protein, lemak, vitamin C, karbohidrat, dan mineral seperti $\mathrm{P}, \mathrm{K}$, $\mathrm{Ca}, \mathrm{Mg}, \mathrm{Fe}$. Gugus fungsional pada terung pokak ada 7 tipe yaitu, fenol, alkana, alkena, nitro, cicncin aromatis, amida danamina, alkohol.

\section{Daftar Pustaka}

Anam , Choirul, Sirojudin dkk, 2007. Analisis gugus fungsi pada sampel uji , bensin, dan spiritus menggunakan metode Spektroskopi FTIR Berkala Fisika Vol.10 no.1. 79-85.

Balachandran C, Emi N, Arum Y, Yamamoto Y, Ahilan B, Sangeta B, Duraipandiyan $\mathrm{V}$, Inaguma $\mathrm{Y}$, Akinao $\mathrm{O}$, Ignacimothu $\mathrm{S}, \mathrm{Al}$ Dhabi NA, and Perumal PT, 2015. In Vitro Anticancer Activity Of Methyl Caffeat Isolated From Solanum torvum, Fruit. Jurnal homepage: www. Elsevier.com/locate//Chembiont. India

Basset, J., R. C. Denney, G. H. Jeffrey, J. Mendhom. 1994. Buku Ajar Vogel Kimia Analisa Kuantitatif Anorganik. Jakarta : EGC

Bernhoft A. 2010. A Brief Review on Bioactive Compounds in Plants in : Bioactive Compounds in PlantsBenefits And Risks for Man And Animals Berhoft, A (Ed). Olso: The Norwegion Academy of Science and Letters.

Chah KF, Muko KN, and Oboegbulem SI, 2000. Antimicrobial Activity of Methanolic Extract of Solanum torvum Fruit. Short report. Fitoterapia. Nigeria.

Departemen Kesehatan RI, 1995. Farmakope Indonesia Edisi IV.
Jakarta: Departemen Kesehatan RI. Hal 1033

Dorly, 2005, Potensi Tumbuhan Obat Di Indonesia Dalam Pengembangan Pengembangan Industri Agromedis, Pengantar Falsafah Sains (PPS 702)Sekolah Pasca Sarjana/ S3, IPB, Bogor.

Droge W, 2002. Free Radicals In The Physiological Control Of Fungtion. Physiol rev. 84 (47) : 4795.

Harborne,J.B. 2006. Metode Fitokimia. Edisi ke - 2. Bandung : ITB.

Jaiswal BS, 2012. Solanum Torvum: A Revie Of Its Traditional Uses. PhytoChemistry And Pharmacology. International Jurnal Of Pharma And Bio Sciences, SOS in Pharmaceutical Sciences. Jiwaji University. Cwalior. India

Karmakal K, Islam MDA, Chanda SA, Tuhin TI, Muslim T, and Rahman Md A, 2015. Secondary Metabolites From The Fruits Of Solanum torfum SW. Journal of Pharmacognosy and Phytechemistry.4(1) : 160163. Departement Of Chemistry University Of Dhaka.Banglades

Langeland, K.A and Cherry, H.M., 2008. Identification And Biology Of Nonnative Plants in Florida Natural Areas. Jurnal edisi 2 Universitas of Florida -IFAS Pub SP 257.

Mahadeva RUS, and Thenmozhi A, 2012. Compareative Free Radical Scavenging Potentials Of Different Parts Of Solanum torvum. Basac Research Article. Departement of biochemistry.SRN. Arts and Science College. Chennai 603203. India. 
Marinova D, Ribarova F, and Atanassova M, 2005. Total Phenolics and Total Flavonoids in Bulgarian Fruits and Vegetables. J University Chem Technol Metallurgy. 40 (3).

Meda MA, Lamien CE, Romito M, Millogo J, and Nacoulma OG, 2005. Deternnition of the total phenolic, flavonoid and proline contents in Burkina Fasan honey, as well as their radical scavenging activity. Food Chemistry. Vol.91 (571-577).Elsevier.

Mohan M, Kamble S, Gadhi P, and Kasture S, 2010. Protective Effect Of Solanum torvum On Doxorubicin- Induced Nephrotoxicity In Rats . Jurnal Food and Chemical Toxicology.India.

Ortega, N., Romero, M.P.,Macia,A., Reguant, J., Angles,N., Morello, J.R.,Motilva, M.J.2009. Comperative studiof UPLC-MS and HPLC-MS/Msto determine procynianidins and alkaloids in cocoa samples.Journal of Food Composition and Analysis. Taragona,Spain

Rahayu YD dan Ginanjar SF, 1997. Analisa Kadar Air dan Kadar Abu Bahan Pangan. USDA Nutriten. Hhttps://id.scribd.com.

Silviyah S, Chomsin, Widodo, Masruroh, 2016. Penggunaan Metode FTIR ( Fourier Transform Infra red) Untuk Mengidentifikasi gugus fungsi Pada Proses Pembaluran Penderita Mioma, jurnal, Jurusan MIPA, UB Mlg

Sloan AE, 2002. The top 10 functional food trends the next generation. Food Technology. 56(4): 32:57.
Stevanie, Fidriani I, dan Elfahmi, 2007. Telaah Kandungan Kimia Ekstrak n- Heksana Buah Takokak(Solanum torvum). Skripsi. Farmasi ITB.

Sunarmi T, 2005. Aktivitas Antioksidan Penangkap Radikal Bebas Beberapa Kecambah Dari Biji Tanaman Familia Papilionaceal, Jurnal Farmasi Indonesia 2(2):5360.

Sudarmadji, S. dkk. 1997. Prosedur Analisa Bahan makanan dan Pertanian. Liberty. Jogjakarta.

Venkatesan S, and Sujitha SDA, 2007. Influence of Genotype Manufacturing Process on The Activity of B-D- Glucosidase And B- Galactosidase In Tea. American Journal of Plant Physiology. 2(2): 175-182.

Wannasiri S, Chansakaow S, and Sireeratawong S, 2017. Effects of Solanum torvum Fruit Water Extract On Hyperlipidemia And Sex Hormones In High-Fat Fed Male Rats. Asian Pacific Jurnal of Tropical Biomedicine. Thailand :7(5). 401-405.

Yuan-Lu, Y, Guang LJ, and Yi K, 2011. Chemical contituents from Solanum torvum. Chinese Journal of Natural Medicines-.9 (1) : 00300032.China. 